\title{
A espetacularização da vida na reprodução humana assistida: uma reflexão necessária ${ }^{1}$
}

\author{
Life spectacularization at human assisted reproduction: a necessary reflection
}

\author{
Carla Froener Ferreira* \\ Marcos Catalan ${ }^{* *}$
}

\section{Resumo}

Ambientado no espetáculo pensado por Debord, o artigo emerge entremeio aos choques havidos entre duas dimensões quase nunca concomitantemente exploradas: a reprodução humana assistida e a sociedade de consumo. Tem por hipótese a colonização, pelo Mercado, de espaços que até recentemente só mereciam atenção nas esferas mais íntimas da vida privada e o correlato desprezo, na seara fenomenológica, de importantes deveres jurídicos desenhados, no Brasil, nas últimas décadas, a partir da percepção da fundamentalidade do Direito do consumidor. A partir daí, o artigo explora, inicialmente, a mutação que marca o cotidiano das famílias brasileiras na qual se inclui o adiamento do projeto parental. $O$ texto flui com a análise de promessas de felicidade formuladas nos cenários da reprodução humana assistida para, mais tarde, comprovar a hipótese antecipada ao salientar a existência de riscos que, embora não informados, impregnam a vida de cada vez mais pessoas. O pensamento crítico e a imaginação jus-sociológica serviram como balizas metodológicas na construção de cada parágrafo alinhavado ao longo deste texto. A análise bibliográfica forneceu o necessário suporte à escrita. Ao final, busca-se chamar a atenção para a imperiosidade de maior respeito a direitos fundamentais, dentre os quais pululam a vida, a saúde, o melhor interesse da criança e a proteção do consumidor.

Palavras-chave: Consumo. Fragmentação do Direito. Reprodução humana assistida.

\section{Abstract}

Set in the Spectacle thought by Debord, this research was born at the crossroads identified by the connection of two dimensions of knowledge: the assisted human reproduction and the Consumer Society. It has as hypothesis the colonization of a space historically thought as something private, by the Economy, as well as, the disrespect of a lot of important juridical duties. The article touches some important aspects linked to contemporary family's structure and practices, the postpone of parenthood project, the promises of happiness made in the scenarios of assisted human reproduction and the existence of risks that, although, usually not informed, fill such social contexts. Critical perspective and bibliographic analysis were chosen as method. The research concludes that is necessary to respect fundamental rights, especially, life and health, the best interests of the child and the protection of the consumers.

Keywords: Consumption. Law fragmentation. Human assisted reproduction.

\section{Introdução}

A reprodução humana - e os muitos belíssimos acidentes ${ }^{2}$ por ela gestados - pode ser pensada enquanto processo atado à sucessão de eventos que tem início, em regra e, ao menos por ora, na união

Este artigo foi produzido no desvelar dos projetos de investigação científica: Abrindo fissuras nas paredes da sociedade do espetáculo [442136/2014-5] e Proteção do consumidor à deriva: uma tentativa de aferição do estado da arte, na tutela jusconsumerista, no âmbito do Superior Tribunal de Justiça [407142/2018-5], ambos financiados pelo CNPq.

Mestre em Direito pela Universidade La Salle. Especialista em Direito Civil e Processo Civil pelo Instituto de Desenvolvimento Cultural. Investigadora vinculada ao grupo de pesquisas Teorias Sociais do Direito. Advogada. Canoas - RS - Brasil. E-mail: carlafroener@gmail.com.

Pós-doutor pela Facultat de Dret da Universitat de Barcelona. Doutor summa cum laude em Direito pela Faculdade do Largo do São Francisco, Universidade de São Paulo. Mestre em Direito pela Universidade Estadual de Londrina. Professor no Programa de Pós-Graduação em Direito e Sociedade da Universidade LaSalle. Professor no curso de Direito da Unisinos. Visitor Schollar no Istituto Universitario di Architettura di Venezia. Professor visitante na Facultad de Derecho de la Universidad de la República, Uruguai. Advogado parecerista. Canoas - RS - Brasil. E-mail: marcoscatalan@uol.com.br.

Quantos espermatozoides - e quantos óvulos - são necessários para que surja um embrião? E quantos são desperdiçados, nos processos aperfeiçoados através do tempo, para que uma vida viável venha a existir? Quantas conversas ou contatos mais íntimos que, ao serem interrompidos, não permitiram o surgimento de mais uma vida? Quantas vidas perdidas na forma intrauterina? Quais as chances de uma gravidez a cada contato sexual? Quais as chances de que o nascituro venha a conhecer a luz do dia? Quantas dúvidas? Para muitas delas, é bem possível que a Ciência tenha respostas. Como não afirmar, entretanto, que somos todos belíssimos acidentes da natureza? 
das células germinativas feminina e masculina (MOORE; PERSAUD, 2008, p. 32), e haverá de experimentar seu êxtase no nascimento, isto é, na vinda com vida à dimensão extrauterina, de mais um ser humano. Um processo que, em julho do ano de $1978,{ }^{3}$ vivenciou manifesta e apoteótica mutação quando se comunicou ao mundo a existência de Louise Joy Brown - o primeiro bebê de proveta do planeta - e, que, desde então, tem sido colonizado pelo mercado.

Enfrentando, criticamente, alguns dos desafios postos pelo contemporâneo, este estudo busca explorar questões ligadas ao universo da reprodução humana assistida a partir de uma peculiaridade: o uso de lentes epistêmicas forjadas no espetáculo (DEBORD, 1997, p. 9-137) roteirizado por Debord ${ }^{4}$ na segunda metade do século XX.

Ambientado em um universo em mutação, em um espaço notadamente colonizado pelo mercado, apesar de, por longa data - o que inclui parte substancial do século XX -, ter sido tratado como um assunto estritamente privado (que interessava apenas aos titulares de projetos parentais frustrados e, talvez, aos seus familiares mais próximos), o artigo tem por hipótese a recorrente inobservância de deveres jurídicos constitucionalmente qualificados como fundamentais quando da atuação de entes coletivos que, ao se moverem, almejando lucro, personificam o referido ator social.

Antecipe-se que, em razão do corte metodológico que a informa, esta pesquisa exclui - intencionalmente e sem prejuízo da manifesta relevância teórica desses assuntos - quaisquer reflexões acerca de discussões como: (a) a experimentação de liberdades positivas no exercício de direitos sexuais (SCHIOCCHET, 2016, p. 349-392) e reprodutivos (PIRES, 2017, p. 1014-1019; BUSNELLI, 2016, p. 1447-1478); ou (b) os efeitos benfazejos derivados da dissociação dos fenômenos da fecundação e da gestação (CAMARDI, 2015, p. 07-54; PINELLI, 2016, p. 242-277). Tampouco busca promover a análise pontual de histórias como (c) a delineada na recentíssima discussão, ocorrida na Itália, acerca dos embriões que, tendo sido produzidos na fusão dos gametas de dois casais que buscavam experimentar o projeto parental por meio da fertilização homóloga perante a mesma clínica, acabaram, inadvertidamente, trocados durante a fase de introdução no útero materno, o que deságua em um drama jurídico-existencial bastante trágico (CORTI, 2016, p. 115139) ou a que (d) será narrada a partir da necessidade de solucionar casos que margeiam a possibilidade de resolução de contratos de gestação quando da comprovação de fatos prejudiciais ao feto, imputáveis (ou não) à gestatrix; e, no limite, (e) o direito de exigir o aborto do filho gestado por outrem (GIACOBBE, 2016, p. 590-606).

O percurso a ser percorrido foi pensado para permitir que o leitor: (a) observe importantes aspectos no processo de mutação das famílias brasileiras, em especial no tocante a algumas de suas conexões com a crescente busca da reprodução assistida; (b) entenda como o mercado opera - por meio da publicidade e de outras práticas comerciais que transitam, muitas vezes, por sobre os umbrais da licitude (PITOL, 2017, p. 766-774); e, ainda, (c) identifique a presença de riscos que, embora não informados, pululam no interior das molduras que envolvem as reflexões ora alinhavadas.

Informe-se, enfim, que: (a) o pensamento crítico (FACHIN, 2000, p. 21-170) orientou a lapidação das muitas ideias que, uma vez fundidas umas às outras, deram forma e vida a este texto; (b) a imaginação jus-sociológica antecedeu cada momento de sua redação, ${ }^{5}$ cada ir e vir da pena usada para escrever estas

Lesley Brown e seu marido buscavam, há anos, ter filhos. O diagnóstico: Lesley tinha as trompas de falópio bloqueadas. Percebendo-o, os médicos britânicos Patrick Steptoe e Robert Edwards, especialistas em fertilidade, decidiram tentar algo pioneiro: uma fertilização in vitro, técnica utilizada apenas de modo experimental em animais. Pouco antes da meia-noite de 25 de julho de 1978, no hospital de Oldham em Bristol, nascia o primeiro bebê de proveta do mundo: Louise Joy Brown (FEMINA, 2016).

4 “A 'espetacularização midiática' é discutida pelo crítico Guy Debord, em A Sociedade do Espetáculo. O autor, que se definia como "doutor em nada" e "pensador radical", foi um dos fundadores - junto com artistas e escritores de diferentes países, em 1957, na Itália, da Internacional Situacionista, um movimento internacional de cunho artístico e político que aspirava transformações sociais. Debord acreditava que se devem fazer críticas ao sistema através da criação de 'situações significativas'. Para o autor francês, o capitalismo é um dos grandes problemas da sociedade. O pensamento de Debord tem perspectiva marxista e se concentra na crítica radical ao fetichismo da mercadoria, tal como ela se apresenta no seu modo de produção. Um dos pontos fortes do pensamento debordiano é a crítica radical contra a presença de imagens na sociedade - na sua concepção, elas podem induzir à passividade e à aceitação do capitalismo" (NEGRINI; AUGUSTI, 2013, p. 02).

5 O estilo literário conscientemente incorporado às linhas que carregam consigo os raciocínios aqui grafados, em boa medida, foi imantado pela assunção de postura metodológica denominada "imaginação [jus]sociológica", que visa a capacitar homens e mulheres a navegarem pelos significados de sua época de modo a compreenderem-no, permitindo, assim, a multiplicação das narrativas que chegam até eles. Seus critérios de validade são "narrativos e experimentais" (JACOBSEN; TESTER, 2015, p. 13-14). 
poucas páginas; e (c) a literatura - jurídica e não-jurídica, nacional e alienígena - foi o sopro que deu forma e conteúdo a cada uma das linhas esboçadas ao largo desta investigação científica.

\section{Famílias: arquitetura e movimento}

Muito antes de sua sistematização científica - ao menos nas sociedades ocidentais, legatárias do Cristianismo -, a sacralização da família e a mitificação da figura paterna acabaram por legitimar, de algum modo, a atribuição ao pater famílias da possibilidade de escolher entre a vida e morte dos filhos, ${ }^{6}$ os quais, curiosamente, ser-Ihe-iam atribuídos, recebendo a sua marca, o seu patronímico, tão só pelo fato daquele a ser chamado de pai, de pater, encontrar-se casado com a gestante (AGUIRRE, 2017, p. 271-274). Tais fatores, aliás, também colaboraram na construção do direito de eleger entre a vida e a morte da esposa adúltera, diante da imposição social atada à pretensão de assegurar efetividade ao brocardo pater ist est (ENGELS, 1984, p. 21-42) e da necessidade de garantir, ao menos ficcionalmente, a obediência ao dever de fidelidade.

A arqueologia das famílias ocidentais acaba revelando, ademais, que, em tal processo, à mulher foram reservados papéis explicitamente secundários. ${ }^{7}$ Coadjuvante também na concepção, a mulher deveria dar ao homem filhos saudáveis, devendo, portanto, possuir um "bom" ventre. Daí que os problemas no campo da infertilidade acabavam por ser atribuídos, com exclusividade, à esposa, embora, curiosamente, aos olhos do direito privado, a impossibilidade de gerar filhos não viesse a legitimar a dissolução do casamento (MIRANDA, 1955, p. 266-275). Tais casos não eram tratados como hipótese de erro essencial sobre a pessoa.

O $\S 3^{\circ}$ do cânon 1084 do Codex luris Canonici, ${ }^{8}$ o silêncio que ainda emana das codificações civis decimonônicas e os aromas que emergem de turíbulos que, impregnados de senso comum, obnubilam a percepção da sacralidade que informa muitas das regras do direito das famílias no Brasil ajudam a percebê-lo, mormente, quando se nota que tais roteiros regeram e ainda regem a vida de muitas famílias e, antes disso, de muitos seres humanos.

Hodiernamente, entretanto, entremeio ao contato constante com espectros vindos do passado e que insistem em transitar por entre as muitas sombras que ganham forma no contexto do senso comum, parece impossível não perceber a náusea incitada pelo movimento de fragmentação e reconfiguração da arquitetura familiar e, ainda, pela bruma gerada pelo avanço prometeico da técnica em searas como a biotecnologia, a robótica e o transumanismo. E é assim que, em alguma medida, das fendas abertas no atrito havido entre o Direito e a sociedade sociedade, emergem, nos campos outrora semeados, por intérpretes da pandectística, com as sementes do purismo conceitual, importantes mutações na seara da práxis.

Exsurgem famílias eudemonistas, famílias esboçadas com tons alegres sobre telas retratando as

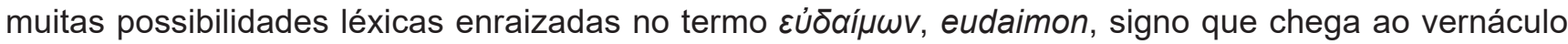
podendo ser significado enquanto caminho até a felicidade - estado de espírito ou ilusão, pouco importa aqui -, caminho por meio do qual, portanto, o exercício de incomensuráveis liberdades positivas (RUZYK, 2010, p. 211-339) poderá vir a ser vivenciado em concreto, independentemente de expressa permissão legislativa, nos múltiplos espaços de coexistência, ternura e afetividade (FACHIN, 2003, p. 17), fundidos (ou não) aos incomensuráveis núcleos conjugais e (ou) parentais existentes na dimensão fenomênica.

Também por isso uma família, atualmente, não pressupõe, como exigido até pouquíssimo tempo pelo Direito no Brasil, o casamento. A sua constituição dispensa relações sexuais, deixando de ser um lenitivo hipócrita para a concupiscência. Ela não exige, ademais, sequer e (ou) exclusivamente, pessoas com sexos distintos ante a valorização do gênero: do gênero humano.

\footnotetext{
Sobre o tema, sugere-se a leitura de Ariès (1981)

Sobre o tema, sugere-se Veyne (2009).

"Can. 1084 - § 1. Impotentia coeundi antecedens et perpetua, sive ex parte viri sive ex parte mulieris, sive absoluta sive relativa, matrimonium ex ipsa eius natura dirimit. $\S 2$. Si impedimentum impotentiae dubium sit, sive dubio iuris sive dubio facti, matrimonium non est impediendum nec, stante dubio, nullum declarandum. § 3. Sterilitas matrimonium nec prohibet nec dirimit, firmo praescripto can. 1098".
} 
É preciso aclarar ser evidente que haverá, igualmente, outras incontáveis relações humanas que apesar de manifestamente marcadas pelo convívio público e duradouro, por conexões ou fios biológicos dos mais variados matizes, ou mesmo configuradas por meio de arranjos genéticos estatisticamente pouco frequentes - não receberão molduras que as identifiquem como um ajuste familiar (BRASILEIRO; HOLANDA, 2014, p. 495-497).

É possível afirmar agora, desenhado o cenário no qual as famílias vivenciam explícito e manifesto processo de mutação, que ajustes normalmente diárquicos - às vezes, anárquicos - parecem ter influenciado a derrocada de um modelo hierarquicamente formatado para submeter, de modo servil e a quase todos, aos mais pueris caprichos de um ser que, muitas vezes, no exercício do papel de chefe de família (CARVALHO SANTOS, 1953, p. 8-12), em regra, atraía para si os atributos de proprietário - nobre, aristocrata ou burguês, pouco importa aqui - e, ainda, de contratante e testador, preferencialmente nessa ordem, qualidades que deveriam ser antecedidas, inexoravelmente, por outro adjetivo: masculino.

A apreciação crítica da arquitetura jurídica das famílias brasileiras permite, ainda, rasgar outros véus legados pelo senso comum. Nelas, sequer filhos são necessários (FONSECA, 2005, p. 51-52). Double income, no kids. Um a cada cinco casais, no Brasil, ${ }^{9}$ vivencia o contexto no qual a prole não é pensada como dever, tampouco como o resultado esperado da experimentação de necessidades biológicas.

Ressignificados enquanto ideia, os filhos exsurgem no presente como frutos de projetos de vida a serem experimentados (ou não) (BAUDIN; DE LA CROIX; GOBBI, 2012) consoante os roteiros eleitos pela Fortuna ou, se preferir o leitor, consoante os caprichos da deusa Libera e, ainda, com lastro nas múltiplas e, quase sempre, não antecipáveis variáveis que poderão informar as vidas de cada ser humano, mesmo que, é preciso reconhecer, a Medicina possa facilitar o acesso aos projetos parentais em muitas ocasiões.

E caso esse venha a ser o caminho a ser eleito, a ser experimentado - se é que se trata de opção em muitas das situações havidas nos campos das relações sociais ${ }^{10}-$, os recentes avanços da técnica permitirão driblar muitas das limitações biológicas identificadas, até bastante recentemente, como barreiras manifestamente intransponíveis nos cenários da reprodução humana (CERUTTI, 2016, p. 14-30). Uma revolução que, como antecipado no preâmbulo deste artigo, teve início em julho de 1978, na Inglaterra, com o nascimento de Louise Brown. Louise, o primeiro bebê de proveta. Um processo que, deste lado do Atlântico, exigiu um pouco mais de espera - Ana Paula nasceu, na cidade de Curitiba, em outubro de 1984 (FEMINA, 2016) - e que, certamente, ainda não recebeu seu ponto final.

Aliás -descartada aqui a clonagem humana, também pela violência ética que ela representa e potencialmente difunde -, embora a procriação siga, ainda, a depender da união dos gametas masculino e feminino (HÉRITIER, 2000, p. 98), os avanços no campo da técnica desarticularam a relação causal natural (STRATHERN, 2009, p. 30) pressuposta até recentemente em tais contextos, ao permitir, por exemplo, a procriação sem contato sexual, a dissociação entre ascendência genética, maternidade e gestação e, ainda, a fusão de óvulos e de estruturas embrionárias (CASTRO, 2016, p. 728).

Transformações que permitem que intervenções médicas produzam a vida por meio: (a) do recurso a procedimentos aptos a agenciarem o approach entre espermatozoides e óvulos, e entre aqueles e o útero feminino; (b) da fusão dos gametas dos titulares dos projetos parentais ou de terceiros no interior do corpo da mãe ou da mulher disposta a exercer o papel de gestatrix (CERUTTI, 2016, p. 20-21) de forma gratuita - no Brasil, a onerosidade é vedada - ou, ainda, entre outras possibilidades, (c) da implantação de embriões na mucosa intrauterina feminina (ALVES, 2014, p. 68).

Uma pesquisa realizada pelo IBGE revela que o "arranjo familiar com parentesco mais comum foi o composto por casal com filhos, mas houve diminuição desse indicador no período: de 51,0\%, em 2004, passou a 42,9\%, em 2014 . O arranjo formado por casais sem filhos tem ganhado importância e se tornou o segundo em participação [19,9\% em 2014], enquanto a proporção de arranjos formados por mulher sem cônjuge e com filhos diminuiu ligeiramente a participação no período. Outros tipos de arranjos correspondiam a 6,3\% do total de arranjos em 2014" (IBGE, 2015, p. 40).

10 Sobre o tema, sugere-se Schütz (2012). 
Mutações que levam a antever, ainda, em cenários marcados pela complexidade, que a emancipação da mulher também influencia a reprodução humana, eis que a gravidez segue sendo adiada, ${ }^{11}$ consoante pode ser observado na leitura de dados produzidos pelo Ministério da Saúde apontando que o percentual de mães aos 30 anos (ou mais) saltou de 22,5\%, no início do século, para 35,1\%, em 2018, como mostra o gráfico abaixo.

\section{Gráfico 01 - Maternidade tardia no Brasil.}

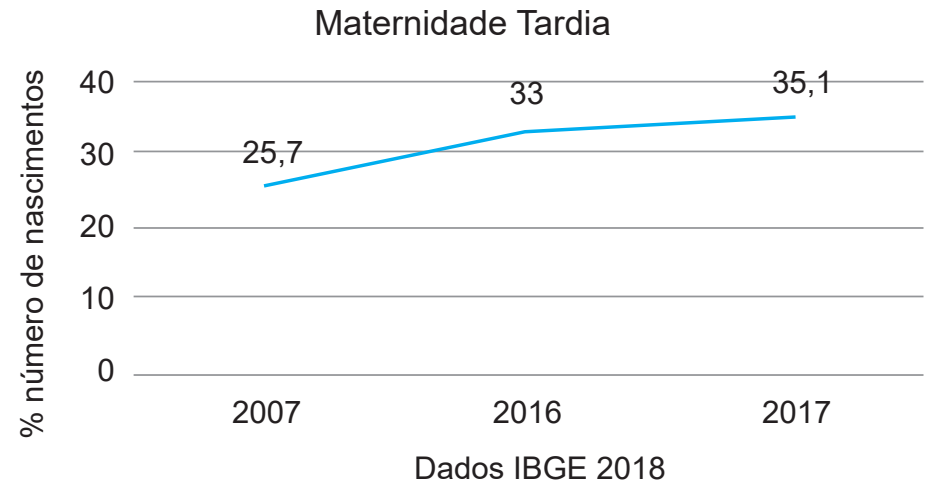

Fonte: IBGE

É patente que, envoltas por tal contexto, muitas dessas mulheres - privadas, por Chronos (ou não), de óvulos em quantidade e (ou) com a qualidade exigida por Afrodite - terão de recorrer ao auxílio da técnica caso queiram vivenciar o projeto parental (FONSECA; HOSSNE; BARCHIFONTAINE, 2009, p. 236).

Evidentemente, a reprodução humana assistida - além de driblar alguns dos inúmeros problemas de fertilidade provocados, como adiantado no parágrafo anterior, pela não priorização da gravidez na juventude - poderá viabilizar o exercício da parentalidade noutros inúmeros contextos, facultando, até mesmo, o uso de gametas e (ou) do útero alheio (FONSECA; HOSSNE; BARCHIFONTAINE, 2009, p. 236) para a experimentação de projetos parentais, de produções independentes ou da coparentalidade, embora não se possa ignorar que tais fenômenos vêm recebendo, do direito, respostas que flutuam ao sabor de conveniências ideológicas, religiosas, geográficas e políticas, tampouco desprezar aspectos imantados ao birth power (BUSNELLI, 2016, p. 1469), em especial no que pertine a deveras questionável disponibilidade do status familiar (VENUTI, 2015, p. 266-273), temas que, como pode perceber o leitor atento, transbordam o corte metodológico que informa esta investigação científica.

Ao mesmo tempo, a reprodução humana se espraia pelo dantesco campo da seleção genética. Em alguns cenários, poderão existir ${ }^{12}$ linhas muito tênues entre as expectativas subjetivamente construídas pelos titulares dos projetos parentais e práticas eticamente contestáveis, ${ }^{13}$ por se aproximarem perigosamente da eugenia e possibilitarem desde a escolha de embriões que não possuam alterações cromossômicas ${ }^{14}$ até a seleção minudente de características, como sexo e cor da pele e (ou) dos olhos do futuro bebê; e, em um cenário bastante próximo, é factível supor, da tonicidade muscular, da altura e dos coeficientes de inteligência (SANDEL, 2013, p. 19; RAMíREZ-GALVEZ, 2009, p. 90).

A propagação de métodos contraceptivos, a ênfase dada à realização profissional e a busca de estabilidade financeira, bem como a recomposição de núcleos conjugais, são algumas das principais causas deste fenômeno.

2 As leituras a seguir apontadas ensejam algumas reflexões deveras importantes acerca do tema: Sandel (2013); Harari (2016).

13 Ao tratar sobre os limites morais da eugenia, Habermas (2004, p. 84-87) afirma que a programação eugênica restringe a liberdade de escolha da vida própria em prol das preferências pessoais dos genitores. Tais intervenções buscam o aperfeiçoamento, mas o fazem de forma irreversível, impedindo a pessoa de se compreender livremente como autor único de sua vida.

14 Consoante os autores Wolff, Martinhago e Ueno (2009, p. 297), o diagnóstico genético pré-implantacional permite a seleção de embriões saudáveis obtidos por meio de programas de fertilização in vitro antes de serem transferidos para o útero materno. A técnica é extremamente invasiva, consistindo na análise de um pequeno fragmento do embrião, no qual é possível identificar aberrações cromossômicas. 
Práticas que, consoante recentemente identificado, em alguma medida, não podem ser dissociadas, por completo, do aborto seletivo de fetos do sexo feminino ${ }^{15}$ detectado na Índia enquanto efeito colateral - tão indesejado quanto cruel -, fundido aos muitos tons de incerteza (OST, 2002, p. 597-626) que tingem as telas sobre as quais a contemporaneidade registra, dia após dia, alguns dos incomensuráveis instantes existenciais que informam a coexistência humana, bem como permite identificar na fenomenologia incontáveis momentos marcados pelo não direito.

A seu turno, a catalogação de perfis genéticos de doadores e fornecedores de gametas - e nem sempre há gratuidade no ato, permita-o, ou não, o Direito pátrio - emerge, aqui, como outra questão deveras preocupante (GARCÍA, 2015, p. 21-45). Nesse ambiente, seres demasiadamente humanos têm tido suas características físicas, intelectuais e genéticas mapeadas e explicitadas em catálogos explorados por aqueles que buscam espermatozoides e óvulos alheios para a realização de projetos parentais.

O ser humano foi transformado em mercadoria (BAUDRILLARD, 2011, p. 11-46). A vida passou a ser ofertada em sites e em outdoors. O mercado explora o fetiche genético da filiação (LUNA, 2007, p. 398), pelo menos quando se tem em mente o seleto grupo que pode pagar por mais experiência. Tais práticas estimulam o perigoso flerte com a hipervalorização (CATALAN; SILVA, 2015, p. 22) da prova biológica e poderá ameaçar o universo parental ao exponeciar, em alguma medida, a dificuldade de enxergar e, consequentemente, entender a explícita diferença que demarca os contornos dogmáticos que albergam, de um lado, a origem genética e, de outro, o estado de filiação (CERUTTI, 2011, p. 60-69; LÔBO, 2004, p. 48).

Tanto é verdade que a aludida confusão acabou influenciando a construção da tese de que "a paternidade socioafetiva, declarada (ou não) em registro público, não impede o reconhecimento do vínculo de filiação concomitante baseado na origem biológica, com os efeitos jurídicos próprios", consoante frisado recentemente pelo Supremo Tribunal Federal, por ocasião do julgamento da Repercussão Geral 622. ${ }^{16}$

Eis, aqui, algumas das muitas questões que levam a concluir quão difícil é não enaltecer a relevância da reprodução humana assistida - ainda que espetacularizada, consoante se procura demonstrar ao longo deste texto - enquanto ferramenta de afirmação da afetividade (LÔBO, 2010, p. 47-52) nas relações familiares que se espraiam pelas mais distintas paisagens da geografia brasileira e, por que não, da geografia global.

De fato, como grafado na introdução, há prismas de análise que permitem vislumbrá-la em suas cores mais vibrantes e alegres, mormente quando se tem em mente muitos dos frutos colhidos - melhor seria dizer, paridos - no exercício de direitos sexuais e reprodutivos (SCHIOCCHET, 2016, p. 349-392; BUSNELLI, 2016, p. 1447-1478). Um tema que, reafirme-se, encontra-se semeado em campos que ultrapassam as fronteiras metodológicas que emolduram esta investigação.

De outra banda, produzida na união de gametas dos titulares do projeto parental (ou não), gestada por aquela que produziu o óvulo (ou não), fato é que a filiação haverá de ser vivenciada, independentemente de existirem eventuais conexões biológicas e (ou) genéticas entre as múltiplas personagens que podem ser envoltas pelo direito das famílias. A questão, aliás, encontra tutela abstrata na arcaica codificação civil (art. 1593) vigente no Brasil, e não apenas nas múltiplas possibilidades de densificação do princípio da inocência (FACHIN, 2003, p. 22-320) - usualmente denominado melhor interesse da criança -, não obstante,

15 O avanço das tecnologias de identificação de sexo e a cultura de preferência aos filhos do sexo masculino têm levado a Índia ao aumento exponencial de abortos de fetos do sexo feminino. Nas últimas décadas, o número de nascimento de mulheres está cada vez menor em relação à população masculina, gerando um problema social. A gravidade da situação conduziu o Legislativo indiano a legislar proibindo que médicos e clínicas divulgassem o sexo do bebê aos genitores, sob pena de sanções, obrigando, ainda, que todas as máquinas de ultrassom sejam registradas e fiscalizadas pelo governo, com objetivo de coibir abusos (MOHANTY, 2015, p. 98).

16 "No caso decidido no RE 898.060/SP, escolhido como leading case [...], é possível verificar pela leitura da sentença prolatada pelo Juízo da $2^{2}$ Vara da Família da Comarca de Florianópolis, bem como dos acórdãos proferidos pelo Tribunal de Justiça do Estado de Santa Catarina, que a autora, F. G., é filha biológica de A. N., o que restou comprovado pelo resultado dos exames de DNA produzidos no curso do processo. Todavia, a autora foi registrada como filha de I. G., quando de seu nascimento, dele recebendo, por mais de vinte anos, os cuidados de pai. O acórdão de origem reconheceu a dupla parentalidade, dispondo acerca dos efeitos jurídicos decorrentes do vínculo genético relativos ao nome, alimentos e herança. Contra essa decisão insurge-se o pai biológico, através [sic] da interposição do Recurso Extraordinário ora em comento, sustentando a preponderância da paternidade socioafetiva em detrimento da biológica, com fundamento nos artigos $226, \S \S 4^{\circ}$ e $7^{\circ}, 227$, caput e $\S 6^{\circ}, 229$ e 230 da Constituição Federal, posto existir vínculo de parentalidade socioafetiva previamente reconhecido e descoberta posterior da paternidade biológica" (AGUIRRE, 2017, p. 284) 
em alguma medida, tais soluções se encontrem alocadas em espaços deveras distantes dos pontos que exsurgem nas intersecções havidas entre a reprodução humana assistida e o espetáculo estimulado, diuturnamente, pelos "desígnios da razão mercantil [que conduz] à sujeição [do ser] e [muitas vezes] à negação da vida real” (FREIRE FILHO, 2003, p. 37).

\section{A colonização da reprodução humana assistida pelo mercado: sobre felicidade, frustração e outros problemas mais graves}

O prisma que informa as reflexões ora alinhavadas permite identificar que a reprodução humana, ao ser colonizada pelo mercado, roteirizou um espetáculo capaz de subverter a realidade e limitar, em alguma medida, a experiência humana à contemplação do não real, à sublimação de imagens e de aparências (DEBORD, 1997, p. 15-18) e (ou) ao culto à superficialidade, redutora da complexidade ao nível do visível (SOUZA, 2014, p. 250). No espetáculo roteirizado por Debord, os seres humanos são espectadores (DEBORD, 1997, p. 24) que vivenciarão, a cada escolha, situações que oscilam entre estados contemplativos e algum nível de interação (SASSATELLI, 2012, p. 79-160), como se afere no relato nada novo de que médicos ingleses, pioneiros na reprodução da vida, antes mesmo de divulgarem suas conquistas em revistas especializadas - valorizando a ciência -, teriam vendido suas histórias para um jornal londrino (CORREA, 1997, p. 75; DINIZ, 2000, p. 02).

Aliás, no Brasil, muito antes de a reprodução humana assistida ser oferecida ao grande público - e, percebam, o recurso da fertilização assistida não ocorre apenas no uso de técnicas tão complexas quanto economicamente onerosas -, a mídia televisiva a explorava como se a imagem fosse capaz de preceder a realidade, consoante antevisto pela genialidade visionária de Debord.

Em 1990, estreou, na televisão brasileira, a novela "Barriga de aluguel". Nela, a fertilização in vitro e a maternidade por substituição permeavam os dias - e a angústia - vividos pela mãe genética e autora do projeto parental, em sua luta pela guarda do filho custodiado pela gestatrix, tratada, na novela, como mãe substituta (CATALAN, 2012, p. 144). Duas décadas mais tarde, em 2012, a novela "Fina estampa" narrou a história de uma mulher cujos óvulos foram manipulados sem o seu consentimento e implantados em uma mulher que buscava gerar um ser, sonhando ter um filho pela via biológica, apesar de sua reconhecida infertilidade (CORREA; LOYOLA, 1999, p. 203).

É curioso notar como ambos os roteiros buscados nos porões da memória culminaram em dramáticas batalhas judiciais questionando a titularidade da parentalidade das crianças, embora, em momento algum, tenham estimulado, de fato, a promoção de qualquer discussão mais densa acerca dos limites éticos e (ou) jurídicos fundidos à reprodução humana assistida e (ou) à complexidade atada à experimentação de projetos e responsabilidades parentais.

Da ficção à vida cotidiana, faz-se oportuno apontar, ademais, que a abordagem midiática costuma descrever as tecnologias de reprodução humana como práticas extremamente simples, bastante acessíveis e inegavelmente inofensivas - mormente por meio de belas imagens criadas pela indústria publicitária (FERREIRA, 2016) ${ }^{17}$-, sem quaisquer referências às baixas taxas de sucesso, aos riscos à saúde ou aos elevados custos financeiros (CORREA; LOYOLA, 1999, p. 217-224) que estão comumente acoplados a tais procedimentos.

Um espetáculo alocado nos palcos do capitalismo avançado e, portanto, encenado em alguns dos espaços cenografados por um sistema econômico que parece acreditar na possibilidade de desenvolvimento infinito - ao criar, de forma ininterrupta, uma miríade de pseudonecessidades (DEBORD, 1997, p. 34) em sua corrida frenética pelo lucro expectado na colonização de muitos dos setores da vida privada (FREIRE FILHO, 2003, p. 35) - e, ao mesmo tempo, despreza as suas muitas contradições e incongruências (JAPPE, 2013, p. 15-230).

\footnotetext{
17 No primeiro dos anexos apensos ao trabalho, a pesquisadora - ora coautora - mapeou os sites de mais de 100 clínicas de reprodução humana assistida no Brasil. O trabalho pode ser encontrado na Biblioteca da Unilasalle, em Canoas.
} 
Há muita dramatização, mas quase nenhuma informação (FERREIRA, 2016), apesar do sem número de comandos que pulsam do reconhecimento, no Brasil: (a) da fundamentalidade do direito do consumidor e (ou) da miríade de regras que atribuem densidade a esse direito, obrigando a avisar, a comunicar, a explicar, a orientar e (ou) a advertir, bem como (b) da mesmíssima fundamentalidade utilizada para significar a força normativa do princípio do melhor interesse da criança (BALLESTÉ, 2012, p. 89-108) e (ou) da inafastável leitura de todas as regras que gravitam caoticamente ao redor do referido princípio constitucional. $E$ tudo isso sem que se explicite - ao menos quando se olha através do prisma eleito para a análise aqui conduzida - maior preocupação com a tutela da dignidade humana quando se afere que vidas foram transformadas em bens de consumo.

Em tal contexto, com a permissão do Direito ou à margem dele, caminhando por sobre os seus umbrais ou se protegendo de algumas de suas muitas zonas impregnadas da mais absurda incerteza, o mercado expandiu-se por sobre o universo da reprodução humana assistida, colonizando-o com suas práticas e discursos. É difícil não perceber como a racionalidade econômica se fundiu ao exercício da Medicina também nessa seara. Diagnósticos e terapias, fármacos, próteses, equipamentos e filhos são ofertados como se fossem bens de consumo (RAMíREZ-GALVEZ, 2009, p. 86), tais quais o são roupas, sapatos, telefones celulares e televisores.

Sem perceber que são personagens nesse processo, os consumidores acabam sendo consumidos (BAUMAN, 2008, p. 64-73) por promessas que costumam garantir, de forma sutil, é verdade, que a felicidade será experimentada na próxima compra, viagem e, por que não, na viabilização do projeto parental há algum tempo adiado em razão de um sem número de razões que não precisam ser aqui colacionadas.

A pesquisa permitiu identificar, por exemplo, que a infertilidade pensada, entre 1960 e 1980, como uma patologia eminentemente social que poderia vir a ser tratada ou, em boa medida, amenizada por meio da adoção de crianças órfãs ou separadas da autoridade parental por outro motivo qualquer, passou a ser difundida como problema de ordem pessoal e para a qual, obviamente, há soluções que podem ser compradas (DINIZ, 2001, p. 01), especialmente por aqueles que possam pagar por elas ou estão dispostos a financiar a materialização de sonhos que algumas vezes não são seus. Comprova-o o fato de que, apenas no ano de 2012, nos Estados Unidos, o setor movimentou algo em torno de 3,5 bilhões de dólares (TIME, 2014) ${ }^{18}$ ou, ainda, o fato de que, no Brasil, em 2017, 146 clínicas de reprodução humana assistida produziram 340.458 oócitos, congelaram 78.216 e transferiram 68.891 embriões (ANVISA, 2018, p. 02-18), sem que se saiba exatamente quantos bebês vieram ao mundo. Foi possível perceber também o surgimento de conglomerados empresariais ofertando fertilidade, aliando técnicas médicas e conhecimento empresarial - como o que informa a atividade publicitária -, seduzindo e conquistando clientes e, consequentemente, ocupando as melhores posições em termos concorrenciais (IKEMOTO, 2009, p. 280-282) e, talvez, melhor cotação nas bolsas de valores.

Um negócio que se expande através do globo, conectando profissionais e instituições médicas médicos, clínicas e hospitais -, agenciadores e intermediários, bancos de genes, produtores de gametas e, até mesmo, mulheres literalmente dispostas a gestar o sonho alheio. Mais recentemente, aliás, grupos econômicos - situados em países nos quais os custos da reprodução são menores, possuem maior oferta de gametas ou, ainda, regras mais permissivas e capazes de legitimar e (ou) desburocratizar o acesso à surrogacy e (ou) ao registro de filhos que surgem na fusão das cores buscadas nas paletas LGBTI+ ${ }^{19}$ têm estimulado o que se convencionou denominar turismo reprodutivo, e alguns dos pacotes oferecidos incluem, além de todo o tratamento médico - raramente simples na fenomenologia das relações sociais -, passagens áreas e hotéis de luxo situados nas cercanias de belíssimos centros de compras (IKEMOTO, 2015, p. 291); prometendo, portanto, todo o necessário à experimentação de mais uma deliciosa experiência hedonista (LIPOVETSKY, 2007, p. 11-96).

18 Nos EUA, entre 2004 - ano em que os serviços de reprodução humana assistida passaram a ser monitorados no país - e 2013, houve um aumento de quase $45 \%$ do número de bebês nascidos por meio de técnicas de reprodução humana assistida. Só no ano de 2013 , foram transferidos 73.571 embriões em um universo de 467 clínicas (IKEMOTO, 2009, p. 288).

19 As letras grafadas em caixa alta aludem a lésbicas, gays, bissexuais, travestis, transexuais e interssexuais. "O símbolo + diz respeito à inclusão de outras orientações sexuais, identidades e expressões de gênero" (REIS, 2018, p. 13). 
A reprodução humana tornou-se um produto a ser consumido (BRAGA; AMAZONAS, 2005, p. 17). Colonizada pelo capital, cria demandas que parecem ser cada vez menos espontâneas. Especialistas são, habitualmente, sugeridos por ginecologistas do setor privado (CORREA; LOYOLA, 1999, p. 225). Quem a procura se submete, muitas vezes, a procedimentos de elevadíssimo custo econômico e iguais possibilidades de insucesso (RAMÍREZ-GALVEZ, 2011, p. 67), não se olvidando quão comuns são os diagnósticos de "infertilidade sem causa aparente" (VIERA CHERRO, 2015, p. 356).

Ao mesmo tempo, é possível mapear relatos mostrando que pesquisas médicas sobre as causas da infertilidade e (ou) da baixa fecundidade são pouco incentivadas, pois, consoante a lógica do mercado, será muito mais lucrativo investir em sofisticadas técnicas de reprodução assistida, mormente quando se identifica que a cura para a infertilidade - quando possível e recomendada, evidentemente - será, provavelmente, comercializada uma única vez, enquanto o apoio à reprodução pode ter que ser consumido diversas vezes, mesmo nos casos de êxito, pois há sempre a possibilidade de um novo projeto parental (DINIZ, 2001, p. 02; CARLOS; SCHIOCCHET, 2006, p. 250).

Ademais, há outras tantas questões éticas mascaradas pela espetacularização da reprodução humana assistida. A captura dos óvulos pressupõe a estimulação hormonal por meio de medicamentos que podem disparar efeitos colaterais, com risco, em casos extremos, de morte da paciente (CORREA; LOYOLA, 1999, p. 217). A retirada dos gametas pode ser relacionada a quadros de infecção. O monitoramento da implantação do embrião exige exames invasivos e desgastantes. São elevadas as taxas de insucesso, de casos de gravidez ectópica e de abortamento espontâneo. Além disso, os dados apresentados por veículos oficiais e pelas clínicas geralmente ressaltam as taxas de sucesso da fertilização - no Brasil, o último relatório oficial alude a $76 \%$ de êxito a partir da produção do número médio de 9.3 oócitos por mulher ${ }^{20}$ -, ignorando, entretanto, quantos entre os procedimentos realizados resultaram em implantações bemsucedidas e nascimentos com vida. ${ }^{21}$

A seu turno, casos de gestação múltipla também são deveras comuns, exponenciando os riscos à saúde. ${ }^{22}$ Os bebês, aliás, vêm ao mundo de forma prematura muitas vezes. E há, ainda, pensando no processo de produção do ser gestado, questões relacionadas ao destino a ser dado aos embriões supranumerários fertilizados, por exigência da técnica, para não serem implantados. Enfim, há de se destacar, antes que este texto alcance seus parágrafos conclusivos, que a saúde psicofísica das pessoas que buscam a reprodução humana assistida - em especial, daquelas que apenas experimentam angústia e frustração ao vivenciarem um sem número de infrutíferas tentativas de fertilização - muitas vezes é posta em xeque, ${ }^{23}$ havendo pesquisas que apontam para casos marcados pela dificuldade de assumir a própria história, visto

20 "Média de oócitos por mulher: produzido a partir dos ciclos de fertilização in vitro realizados; descreve-se como o número de oócitos produzidos pelo número de ciclos realizados com pelo menos um oócito captado. Este indicador possibilitará uma avaliação sobre os fatores que contribuem para a Síndrome de Hiperestímulo Ovariano (SHO). Desvios detectados pela análise desse indicador pode ser investigado para a detecção de problemas, como protocolos inadequados de uso de medicamento para estimulação ovariana. Desvios na média não necessariamente indicarão problemas nos protocolos utilizados em medicamentos para estimulação ovariana, pois deve-se considerar fatores com faixa etária e principal morbidade das pacientes atendidas pelo serviço" (ANVISA, 2018, p. 05-06).

21 Dados dos EUA informam que, enquanto as "taxas de sucesso de fertilização" costumam ser entre 65 a $75 \%$, de acordo com as condições pessoais do paciente (idade e saúde), a taxa de nascimento de bebês com vida por implantação embrionária foi de $37,5 \%$, nos EUA, em 2013 . Isto significa que apenas $37,5 \%$ dos embriões implantados resultaram em nascimento com vida (AMERICAN SOCIETY FOR REPRODUCTIVE MEDICINE, 2015, p. 09)

22 O caso da norte-americana Nadya Suleman, a octomãe, é emblemático. Em 2009, ficou conhecida por dar à luz a oito bebês, simultaneamente originários de fertilização in vitro. Nadya, à época desempregada, possuía outros seis filhos também concebidos por meio de técnicas de reprodução assistida, tendo iniciado seus tratamentos aos 21 anos. A octomãe tornou-se celebridade nos EUA, tendo participado de vários reality shows, até lançar a carreira de atriz de filmes adultos. O caso foi duramente criticado pela opinião pública norte-americana, principalmente pela irresponsabilidade de Suleman, que acumulou dívidas milionárias pelos tratamentos e que aparentava não possuir condições financeiras e psicológicas para cuidar de extensa prole, bem como em razão da conduta de seus médicos, pois colocaram em risco a vida da gestante e de seus filhos (GAZETTE REVIEW, 2015).

23 Estudos realizados com pacientes que buscam tratamentos para a reprodução demonstram que tais experiências elevam o nível de estresse e os abalam emocionalmente. A maioria dos participantes de entrevistas e de grupos de apoio fala desse período com grande mal-estar. Lindner, Coelho e Büchele (2013, p. 102-103), em pesquisa empírica realizada com nove médicos da rede pública, constataram que, nas unidades básicas de saúde, a situação de abalo emocional dos pacientes que enfrentam a infertilidade é ainda mais acentuada. Não são oferecidos acompanhamento psicológico e grupos de apoio ou, quando há, o serviço é extremamente precário. As informações são apenas aquelas dadas na consulta médica. 
que os motivos que levam à tentativa de reprodução na forma assistida se revelam, por vezes, entremeio a processos deveras dolorosos e angustiantes, pois, em algumas ocasiões, não é apenas o vazio produzido pela ausência de filhos que conduz alguém a recorrer ao auxílio médico, mas vazios marcados por perdas ao longo da vida, como aborto, a morte de outro filho ou mesmo a ilusão depositada na reconstrução de uma relação conjugal corroída pelo tempo (LINS; PATTI; PERON; BARBIERI, 2014, p. 390).

\section{Na provisoriedade de uma conclusão: a volatilidade de vidas deixadas à deriva}

Como observado ao longo do texto, colonizada pelo mercado, a reprodução humana assistida tem sido roteirizada como espetáculo apto, em alguma medida, a conduzir muitos seres humanos por caminhos prenhes de perigos e riscos difusamente camuflados nas promessas de experimentação de inenarrável felicidade, pretensamente atada aos desafios de ser pai e de ser mãe. $O$ artigo buscou mapear alguns dos possíveis pontos de intersecção havidos no acoplamento do processo de mutação vivenciado pelas famílias brasileiras, especialmente após o advento da Constituição Federal em 1988, com algumas das ações postas em movimento por aqueles que lucram com contratos que têm por objeto a reprodução humana assistida.

De um lado, em ebulição, as famílias brasileiras singram mares e paisagens que, cada vez menos, remetem ao modelo cinzelado nas codificações decimonônicas dos séculos XIX e XX, e mesmo em códigos civis nascidos no século XXI, consagrando modelos que aludem à família unitária, matrimonial, patriarcal e patrimonialista para, cada vez mais, revelarem-se aos intérpretes como algumas das imagens que ocupam telas rabiscadas por Monet ou por Degas, com cores que as aproximam do constitucional, do plural, do diárquico, do democrático e, especialmente, do eudemonista. Entre as sístoles e diástoles sociais que provocam esse movimento, a prole acabou deixando de ser pensada como dever, exsurgindo, muitas vezes, enquanto fruto de projetos de vida a serem vivenciados, tenham sido planejados ou não nos reinos da afetividade.

E é aqui, neste exato instante, que melhor são percebidas algumas das mais explícitas conexões entre a família e a reprodução humana. De um lado, os avanços da técnica desarticularam a relação causal natural pressuposta até pouquíssimo tempo nesses contextos, ao permitirem a experimentação de projetos parentais que, de outra forma, em alguma medida, não poderiam ser vividos; de outro, colonizadas pelo mercado, nem sempre transitam por vias iluminadas pela ética e (ou) pelo Direito.

Tais preocupações parecem ter algum sentido quando se imagina que a reprodução humana margeia o dantesco campo da seleção genética ou são vislumbrados os riscos havidos na catalogação de perfis detalhados dos doadores de gametas, igualmente quando se tem em mente a mercantilização da vida - e de vidas novas - por meio de anúncios em sites, revistas e outdoors e, ainda, o fato de que diagnósticos, terapias, fármacos e filhos são sugeridos e (ou) prescritos como quaisquer outros bens de consumo. $\mathrm{E}$ não seja aqui desprezada a - ao menos, aparentemente - ausência de informação qualificada acerca das baixíssimas taxas de sucesso, dos riscos à saúde ou dos custos financeiros comumente imantados nessas práticas.

E isso ocorre apesar da existência de um sem número de regras e princípios que se propõem a, sistemicamente, tutelar consumidores e crianças no Brasil, criando direitos que são inegavelmente marcados pela fundamentalidade formal e material e que, a seu modo, densificam a promessa normativa de vidas dignas feita a todos que aqui vivem, em 1988, pela Constituição Federal. Tudo isso, ignorando que a vulnerabilidade - e sua inafastável normatividade - deve ser identificada como o pilar que sustenta a própria existência do Direito do consumidor, nos termos do artigo $4^{\circ}$ da Lei n. ${ }^{\circ} 8.078 / 90$.

Art. $4^{\circ}$ A Política Nacional das Relações de Consumo tem por objetivo o atendimento das necessidades dos consumidores, o respeito à sua dignidade, saúde e segurança, a proteção de seus interesses econômicos, a melhoria da sua qualidade de vida, bem como a transparência e harmonia das relações de consumo, atendidos os seguintes princípios:

I - reconhecimento da vulnerabilidade do consumidor no mercado de consumo [...]. 
Vulnerabilidade que, hermeneuticamente, pode ser colorida com tons que remetem:

(a) à frágil posição ocupada pelo consumidor frente à melhor condição socioeconômica do fornecedor ou dos fornecedores envolvidos na cadeia de consumo (CATALAN, 2019, p. 46-47) e que, no contexto delineado neste artigo, por não ser respeitada, pode acabar levando consumidores ao endividamento;

(b) à percepção parcial ou distorcida, à incompreensão ou desconhecimento de aspectos fundidos aos processos produtivos, aos efeitos positivos e (ou) deletérios potencialmente esperados ou, ainda, aos perigos e riscos imantados ao consumo instantâneo ou prolongado de um produto ou serviço qualquer (CATALAN, 2019, p. 46-47), tal qual descrito ao longo da terceira parte deste estudo, cujo limite pode levar à morte das mulheres seduzidas pelo discurso publicitário nos cenários recortados nesta investigação;

(c) à miríade de consequências negativas identificáveis no contexto da dicotomia litigantes habituais versus litigantes eventuais, um tema que começou a ser desnudado por Cappelletti e Garth (1988) em meados do século passado e, desde então, segue a alimentar a expertise jurídica do mercado; e enfim,

(d) ao delicado e indelével equilíbrio atado à adequada densificação do direito à informação, intersecção que exige, de um lado, que a deficiência informativa não se manifeste em concreto e, de outro, que a sua hiperbolização não transforme compreensão em angústia, confusão ou dúvida (CATALAN, 2019, p. 46-47) e que, sem dúvida, ao menos neste momento, não permeia as práticas havidas no contexto da reprodução humana assistida.

\section{Referências}

ANVISA. $1^{\circ}$ Relatório do Sistema Nacional de Produção de Embriões. 2018. Brasília: Ministério da Saúde, 2018.

AGUIRRE, João. Reflexões sobre a multiparentalidade e a repercussão Geral 622 do STF. Revista Eletrônica Direito e Sociedade, Canoas, v. 5, n. 1, p. 269-291, maio 2017.

ALVES, Sandrina Maria Araújo Lopes; OLIVEIRA, Clara Costa. Reprodução medicamente assistida: questões bioéticas. Revista Bioética, Brasília, v. 22, n. 1, p. 66-75, 2014.

AMERICAN SOCIETY FOR REPRODUCTIVE MEDICINE. Assisted reproductive technology. 2015. Disponível em: https://www.asrm.org/uploadedFiles/ASRM_Content/Resources/Patient_Resources/Fact_ Sheets_and_Info_Booklets/ART.pdf. Acesso em: 08 ago. 2016.

ARIÈS, Philippe. História social da criança e da família. Tradução: Dora Flaksman. 2. ed. Rio de Janeiro: LTC, 1981.

BALLESTÉ, Isaac Ravetllat. El interés superior del niño: concepto y delimitación del término. Educatio Siglo XXI, v. 30, n. 2, p. 89-108, dez. 2012.

BAUDIN, Thomas; DE LA CROIX, David; GOBBI, Paula. DINKs, DEWKs \& Co.: marriage, fertility and childlessness in the United States, 2012. Disponível em: https://halshs.archives-ouvertes.fr/hal00993307/document. Acesso em: 14 jun. 2017.

BAUDRILLARD, Jean. A sociedade de consumo. Tradução: Artur Morão. Lisboa: Edições 70, 2011.

BAUMAN, Zygmunt. Vida para consumo: a transformação das pessoas em mercadoria. Rio de Janeiro: Zahar, 2008.

BRAGA, Maria das Graças Reis; AMAZONAS, Maria Cristina Lopes de Almeida. Família: maternidade e procriação assistida. Psicologia em Estudo, Maringá, v. 10, n. 1, p. 11-18, jan./abr. 2005.

BRASILEIRO, Luciana; HOLANDA, Maria Rita. A proteção da pessoa nas famílias simultâneas. In: EHRHARDT, Marcos et al. (org.). Direito civil constitucional: a ressignificação dos institutos fundamentais do direito civil contemporâneo e suas consequências. Florianópolis: Conceito, 2014. p. 495-508.

BRITO, Leila Maria Torraca de. Paternidades contestadas: a definição da paternidade como um impasse contemporâneo. Belo Horizonte: Del Rey, 2008. 
BUSNELLI, Francesco Donato. II diritto della famiglia di fronte al problema della difficile integrazione delle fonti. Rivista di Diritto Civile, Padova, v. 62, n. 6, p. 1447-1478, nov./dez. 2016.

CAMARDI, Carmelita. Diritto findamentali e status della persona. Rivista Critica del Diritto Privato, Napoli, v. 33, n. 1, p. 07-54, giu. 2015.

CAPPELLETTI, Mauro; GARTH, Bryan. Acesso à justiça. Tradução: Ellen Gracie Northfleet. Porto Alegre: Fabris, 1988.

CARLOS, Paula Pinhal de; SCHIOCCHET, Taysa. Novas tecnologias reprodutivas e direito: mulheres brasileiras entre benefícios e vulnerabilidades. Novos Estudos Jurídicos (UNIVALI), Itajaí, v. 11, p. 249263, 2006.

CARVALHO SANTOS, J. M. de. Código civil interpretado: principalmente do ponto de vista prático direito de família. 4. ed. Rio de Janeiro: Freitas Bastos, 1953. v. 4.

CASTRO, Rosa J. Mitochondrial replacement therapy: the UK and US regulatory landscapes. Journal of Law and the Biosciences, v. 3, issue 3, p. 726-735, Dec. 2016.

CATALAN, Marcos. Um ensaio sobre a multiparentalidade: explorando no ontem as pegadas que levarão ao amanhã. Revista da Faculdade de Direito - UFPR, Curitiba, n. 55, p. 143-162, 2012.

CATALAN, Marcos. Uma ligeira reflexão acerca da hipervulnerabilidade dos consumidores no Brasil. In: DANUZZO, Ricardo Sebastián (org.). Derecho de daños y contratos: desafíos frente a las problemáticas del siglo XXI. Resistencia: Contexto, 2019. p. 35-50.

CATALAN, Marcos; SILVA, Giana de Marco Vianna da. Registro de biparentalidade homoafetiva: um estudo de caso. Revista Síntese Direito de Família, São Paulo, n. 92, p. 09-23, out./nov. 2015.

CERUTTI, Eliza. A ancestralidade genética como desdobramento dos direitos de personalidade. In: SOUZA, Ivone Maria Cândido Coelho de (org.). Família contemporânea: uma visão interdisciplinar. Porto Alegre: Letra \& Vida, 2011. p. 60-69.

CERUTTI, Eliza. Gestação por substituição: o que o Brasil pode aprender com a experiência estrangeira. Revista de Nacional de Direito de Família e Sucessões, Porto Alegre, v. 12, p. 14-30, maio/jun. 2016.

CORREA, Marilena. As novas tecnologias reprodutivas: uma evolução a ser assimilada. Physis: Revista Saúde Coletiva, Rio de Janeiro, v. 07, n. 01, p. 69-98, 1997.

CORREA, Marilena; LOYOLA, Maria Andréa. Novas tecnologias reprodutivas: novas estratégias de reprodução?. Physis: Revista Saúde Coletiva, Rio de Janeiro, v. 09, n. 01, p. 209-234, 1999.

CORTI, Ines. Due gemelli e quattro genitori interrogano il diritto - riflessioni in merito all'erroneo scambio di embrioni: ondinanza del Tribunale di Roma 8 agosto 2014. Rivista Critica del Diritto Privato, Napoli, v. 34, n. 1, p. 115-139, mar. 2016.

DEBORD, Guy. A sociedade do espetáculo. Tradução: Estela dos Santos Abreu. Rio de Janeiro: Contraponto, 1997.

DINIZ, Debora. O impacto das tecnologias conceptivas nas relações parentais. Série Anis, Brasília, v. 24, p. 01-05, abr. 2001.

DINIZ, Debora. Tecnologias reprodutivas, ética e gênero: o debate legislativo brasileiro. Série Anis, Brasília, v. 15, p. 01-10, out. 2000.

ENGELS, Friedrich. A origem da família, da propriedade privada e do estado. Tradução: José Silveira Paes. São Paulo: Global, 1984.

FACHIN, Luiz Edson. Direito de família: elementos críticos à luz do novo código civil brasileiro. 2. ed. Rio de Janeiro: Renovar, 2003.

FACHIN, Luiz Edson. Teoria crítica do direito civil. Rio de Janeiro: Renovar, 2000.

FACHIN, Luiz Edson; RUZYK, Carlos Eduardo Pianovski. Código civil comentado: direito de família casamento. São Paulo: Atlas, 2003. v. 15. 
FEMINA CENTRO DE REPRODUÇÃO HUMANA ASSISTIDA. Histórico. 2016. Disponível em: http:// www.reproducaohumanafemina.com.br/medicina-reprodutiva/. Acesso em: 02 ago. 2016.

FERREIRA, Carla Froener. A reprodução humana assistida e a sociedade do espetáculo: a fragmentação do direito frente à publicidade via internet de tratamento de fertilização. 2016. Dissertação (Mestrado em Direito e Sociedade) - Universidade La Salle, Canoas, 2016.

FONSECA, Cláudia. Concepções de família e práticas de intervenção: uma contribuição antropológica. Saúde e Sociedade, São Paulo, v. 14, n. 2, p. 50-59, maio/ago. 2005.

FONSECA, Larissa Lupião; HOSSNE, William Saad; BARCHIFONTAINE, Christian de Paul de. Doação compartilhada de óvulos: opinião de pacientes em tratamento para infertilidade. Revista Bioethikos, São Paulo, v. 3, n. 2, p. 235-240, 2009.

FREIRE FILHO, João. A sociedade do espetáculo revisitada. Revista FAMECOS, Porto Alegre, n. 22, p. 33-46, dez. 2003.

GARCÍA, Francisco Córdoba. La privacidad genética: concepto, fundamentos y consecuencias. In: BORRALLO, Enrique Anarte; MORENO, Fernando Moreno; GARCÍA RUIZ, Carmen (coord.). Nuevos conflictos sociales: el papel de la privacidad. Madrid: Iustel, 2015. p. 21-45.

GATTO, Alessandra. Surrogazione di maternità e diritto del minore al rispetto della propria vita privata e familiare. II diritto di famiglia e delle persone, Milano, v. 44, n. 3, p. 1091-1131, lug./set. 2015.

GAZETTE REVIEW. What Happened to "Octomon" Nadya Suleman? 2015. Disponível em: http:// gazettereview.com/2015/07/what-happened-to-octomom-nadya-suleman-new-updates-available/. Acesso em: 20 jan. 2016.

GIACOBBE, Emanuela. Dell'insensata aspirazione umana al dominio volontaristico sul corso della vita. II diritto di famiglia e delle persone, Milano, v. 45, n. 2, p. 590-606, apr./giu. 2016.

HABERMAS, Jürgen. $O$ futuro da natureza humana: a caminho de uma eugenia liberal? Tradução: Karina Jannini. São Paulo: Martins Fontes, 2004.

HARARI, Yuval Noah. Homo Deus: uma breve história do amanhã. Tradução: Paul Geiger. São Paulo: Companhia das Letras, 2016.

HÉRITIER, Françoise. A coxa de Júpiter: reflexões sobre os novos modos de procriação. Estudos Feministas, Florianópolis, ano 8, $1^{\circ}$ semestre, p. 98-114, 2000.

INSTITUTO BRASILEIRO DE GEOGRAFIA E ESTATÍSTICA. Síntese de indicadores sociais: uma análise das condições de vida da população brasileira. 2018. Rio de Janeiro: IBGE, 2018.

IKEMOTO, Lisa. Reprodutive tourism: equality concerns in the global market for fertility services. Law and Inequality: A journal of Theory and Practice, v. 27, 2009. UC Davis Legal Studies Research Paper Serie, n. 189, 2009. Disponível em: http://ssrn.com/abstract=1462477. Acesso em: 20 fev. 2015.

JACOBSEN, Michael Hviid; TESTER, Keith. Introdução. In: BAUMAN, Zygmunt. Para que serve a sociologia? Tradução: Carlos Alberto Medeiros. Rio de Janeiro: Zahar, 2015. p 11-15.

JAPPE, Anselm. Crédito à morte: a decomposição do capitalismo e suas críticas. Tradução: Robson de Oliveira. São Paulo: Hedra, 2013.

LINDNER, Sheila Rubia; COELHO, Elza Berger Salema; BÜCHELE, Fátima. O discurso e a prática de médicos sobre direitos reprodutivos. Saúde \& Transformação Social, Florianópolis, v. 4, n. 3, p. 98-106, 2013.

LINS, Patrícia Gomes Accioly; PATTI, Elci Antonia de Macedo Ribeiro; PERON, Antonio Cézar; BARBIERI, Valéria. O sentido da maternidade e da infertilidade: um discurso singular. Estudos de Psicologia, Campinas, v. 31, n. 3, p. 387-392, jul./set. 2014.

LIPOVETSKY, Gilles. A sociedade da decepção. Tradução: Armando Braio Ara. Barueri: Manole, 2007.

LOBO, Paulo Luiz Netto. Direito ao estado de filiação e direito à origem genética: uma distinção necessária. Revista CEJ, Brasília, v. 8, n. 27, p. 47-56, out./dez. 2004. 
LOBO, Paulo Luiz Netto. Direito civil: famílias. 3. ed. São Paulo: Saraiva, 2010.

LUNA, Naara. Natureza humana criada em laboratório: biologização e genetização do parentesco nas novas tecnologias reprodutivas. História, Ciências, Saúde, Manguinhos, v. 12, n. 2, p. 395-417, maio/ ago. 2007.

MALUF, Adriana Caldas do Rego Dabus. Curso de bioética e biodireto. São Paulo: Atlas, 2010.

MARQUES, Cláudia Lima. Contratos no código de defesa do consumidor: o novo regime das relações contratuais. 6. ed. São Paulo: RT, 2011.

MASI, Domenico de. A sociedade pós-industrial. In: MASI, Domenico de. A sociedade pós-industrial. Tradução Anna Maria Capovilla et al. 4. ed. São Paulo: Senac, 2003.

MOHANTY, Tapan Rajan. Law, liberty and life: a discursive analysis of PCPNDT Act. Redes: Revista Eletrônica Direito e Sociedade, Canoas, v. 3, n. 2, p. 97-120, nov. 2015.

MOORE, Keith L.; PERSAUD, T.V.N. Embriologia clínica. Rio de Janeiro: Elsevier, 2008.

NEGRINI, Michele; AUGUSTI, Alexandre Rossato. O legado de Guy Debord: reflexões sobre o espetáculo a partir de sua obra. Disponível em: http://www.bocc.ubi.pt/pag/negrini-augusti-2013-legadoguy-debord.pdf. Acesso em: 11 jul. 2019.

OST, François. Tiempo y contrato: crítica del pacto fáustico. Doxa, Alicante, n. 25, p. 597-626, 2002.

PARADISO, Massimo. Navigando nell'arcipelago familiare: Itaca non c'è. Rivista di Diritto Civile, Padova, v. 5, n. 62, p. 1306-1318, set./out. 2016.

PINELLI, Arnaldo Morace. II diritto di conscere le proprie origini e i recenti interventi della corte costituzionale: il caso dell'ospedale Sandro Pertini. Rivista di Diritto Civile, Padova, v. 62, n. 1, p. $242-$ 277, gen./feb. 2016.

PIRES, Teresinha Teles. Procreative autonomy, gender equality and right to life: the decision of the Interamerican Court of Human Rights in Artavia Murillo versus Costa Rica. Revista Direito GV, São Paulo, v. 13, n. 3, p. 1007-1028, set./dez. 2017.

PITOL, Yasmine Uequed; CATALAN, Marcos. El acoso de consumo en el derecho brasileño. Revista Critica de Derecho Privado, Montevideo, v. 14, p. 759-778, 2017.

MIRANDA, Francisco Cavalcanti Pontes de. Tratado de direito privado. Rio de Janeiro: Borsoi. 1955. t. VII.

PORTER, Eduardo. $O$ preço de todas as coisas: por que pagamos o que pagamos. Tradução: Cássio de Arantes Leite. Rio de Janeiro: Objetiva, 2011.

RAMÍREZ-GALVEZ, Martha. Corpos fragmentados e domesticados na reprodução humana assistida. Cadernos Pagu, Campinas, v. 33, p. 83-115, jul./dez. 2009.

RAMÍREZ-GALVEZ, Martha. Inscrito nos genes ou escrito nas estrelas? Adoção de crianças e o uso de reprodução humana assistida. Revista de Antropologia, São Paulo, v. 54, n. 1, p. 47-87, 2011.

REIS, Toni (org.). Manual de comunicação LGBTI+. 2. ed. Curitiba: Aliança Nacional LGBTI / GayLatino, 2018.

RUZYK, Carlos Eduardo Pianovski. Institutos fundamentais do direito civil e liberdade(s): repensando a dimensão funcional do contrato, da propriedade e da família. Rio de Janeiro: GZ, 2010.

SANDEL, Michael. Contra a perfeição: ética na era da engenharia genética. Tradução: Ana Carolina Mesquita. Rio de Janeiro: Civilização Brasileira, 2013.

SASSATELLI, Roberta. Consumo, cultura y sociedad. Buenos Aires: Amorrortu, 2012.

SCHIOCCHET, Taysa. Direitos sexuais a partir de uma perspectiva emancipatória: reconhecimento e efetividade no âmbito jurídico. In: SALES, Gabrielle Bezerra; GONÇALVES, Camila Figueiredo Oliveira; CASTILHO, Natália Martinuzzi (org.). A concretização dos direitos fundamentais na contemporaneidade. Fortaleza: Boulesis, 2016. v. 1. p. 349-392. 
SCHÜTZ, Alfred. Sobre fenomenologia e relações sociais. Petrópolis: Vozes, 2012.

SOUZA, Daniel Maurício Viana de. A teoria da "sociedade do espetáculo" e os mass media. Revista Brasileira de Sociologia, Aracaju, v. 2, n. 4, , p.247-272, jul./dez. 2014.

STRATHERN, Marilyn. A antropologia e o advento da fertilização in vitro no Reino Unido: uma história curta. Cadernos Pagu, Campinas, n. 33, p. 09-55, jul./dez. 2009.

STRECK, Lenio. Dicionário de hermenêutica. São Paulo: Casa do Direito, 2017.

TIME. How high-tech baby making fuels the infertility market boom. 2014. Disponível em: http://time. com/money/2955345/high-tech-baby-making-is-fueling-a-market-boom/\#money/2955345/high-tech-babymaking-is-fueling-a-market-boom/. Acesso em: 10 fev. 2015.

VENUTI, Maria Carmela. Coppie sterili o infertili e coppie "same-sex": la genitorialità negata come problema giuridico. Rivista Critica del Diritto Privato, Napoli, v. 33, n. 2, p. 259-295, giu. 2015.

VEYNE, Paul. História da vida privada: do império romano ao ano mil. São Paulo: Companhia das Letras, 2009.

VIERA CHERRO, Mariana. Sujetos y cuerpos asistidos: un análisis de la reproducción asistida en el río de la plata. Civitas, Porto Alegre, v. 15, n. 2, p. 350-368, abr./jun. 2015.

WOLFF, Philip; MARTINHAGO, Ciro Dresch; UENO, Joji. Diagnóstico genético pré-implantacional: uma ferramenta importante para a rotina da fertilização in vitro? Femina, São Paulo, v. 37, n. 6, p. 297-303, jun. 2009.

Recebido em: 02/02/2019

Aprovado em: 13/05/2019 